\title{
Emotional interpretants and ethical inquiry
}

\author{
Henrik Rydenfelt \\ Department of Social Research, University of Helsinki \\ P.O. Box 38, 00014 Helsinki, Finland \\ e-mail: henrik.rydenfelt@helsinki.fi
}

\begin{abstract}
The connection between emotions and ethical views or ethical inquiry has been considered intimate by a number of philosophers. Based on Peirce's discussion on the emotional interpretants in MS 318, I will suggest that such interpretants could be exploited in ethical inquiry. I will first argue, drawing on T. L. Short's interpretation of Peirce, that there are final emotional interpretants, and such emotional interpretants actually formed (or dynamical) can be more or less appropriate concerning the sign's (dynamical) objects. I will then explore the prospect that emotional interpretants could be harnessed for the particular cognitive purpose of ethical inquiry, concluding that normative judgments based on feelings could serve as its observational part.
\end{abstract}

Keywords: emotion, interpretant, emotional interpretant, final interpretant, inquiry, observation, pragmatism, science

\section{Introduction}

In MS 318, Peirce lays out one of his many trichotomies of interpretants: emotional interpretants are feelings, energetic interpretants actions, and logical interpretants thoughts (or ultimately habits) that interpret a sign. Peirce points out that "not all signs have logical interpretants, but only intellectual concepts and the like" (EP 2: 410). With his usual concentration on logical interpretants, Peirce appears to have given emotional interpretants a rather limited treatment. This does not however imply that such interpretants are of limited interest or useless for many, including cognitive ends. Indeed, in what follows I will suggest - following ways paved by T. L. Short $(2008,2015)$ that emotional interpretants could be exploited for specifically scientific purposes, in particular in normative inquiry such as that of ethics.

According to Peirce's other central trichotomy of interpretants, a sign's immediate interpretant is the possibility of its interpretation; the dynamical interpretant an interpretant actually formed by some interpreter: and the final interpretant the interpretant that would be formed by any interpreter (in some conditions), containing, 
as Peirce somewhat cryptically points out, the "Sum of the Lessons" of the sign concerning its object. Accordingly, for any actually formed, dynamical emotional interpretants to reveal something concerning the sign's object, there must be such things as final emotional interpretants.

In order to explore the possibility of final emotional interpretants, I will first discuss T. L. Short's account of the final interpretant as the interpretant ideally adequate to the purposes of the interpretation of the sign, adjusting this account to fit better some of Peirce's accounts of the final interpretant. I will then proceed to show that emotional interpretants, too, can serve such purposes of interpretation. Finally, I will argue that Peirce's discussion of the emotional interpretants yields the prospect of harnessing such interpretants for a specifically cognitive purposes in ethical inquiry.

\section{Emotional interpretants: immediate, dynamical and final}

To my knowledge, Peirce distinguishes emotional, energetic and logical interpretants by their names only in MS 318, and even there in passing. Emotional interpretants are feelings, energetic interpretants actions and logical interpretants thoughts (and ultimately, habits) that interpret a sign. This is how Peirce describes the first, emotional interpretant:

The first proper significate effect of a sign is a feeling produced by it. There is almost always a feeling which we come to interpret as evidence that we comprehend the proper effect of the sign, although the foundation of truth in this is frequently very slight. This "emotional interpretant", as I call it, may amount to much more than that feeling of recognition; and in some cases, it is the only proper significate effect that the sign produces. Thus, the performance of a piece of concerted music is a sign. It conveys, and is intended to convey, the composer's musical ideas; but these usually consist merely in a series of feelings. If a sign produces any further proper significate effect, it will do so through the mediation of the emotional interpretant, and such further effect will always involve an effort. (CP 5.475)

Another central Peircean division is that between the immediate, dynamical and final interpretants. The immediate interpretant of a sign is its particular interpretability. Peirce's wording already suggests that all signs have an immediate emotional interpretant, which consists at least of the potential interpretability of the sign. In turn, dynamical interpretants are the interpretants actually elicited in the interpreter. Maintaining that any further interpretants are elicited through the mediation of the emotional interpretant, Peirce suggests that feelings are inevitably brought about by any sign actually interpreted, whatever its type: thus all signs actually interpreted have dynamical emotional interpretants. In Peirce's description, the dynamical emotional 
interpretant is at least a feeling of interpretability; as we will see, it can be much more. Moreover, a dynamical energetic interpretant ("effort") is required for the formation of a logical interpretant.

Are there final emotional interpretants? And if there are, are these possessed by all signs that produce dynamical emotional interpretants? A part of the problem in answering these questions is that the notion of a final interpretant is far from clear: Peirce himself admitted, his notion of this third interpretant was "not yet clear from mist" (CP 4.536). Many of Peirce's discussions of the final interpretant suggest that such an interpretant cannot be emotional in nature: the interpretant is of the nature of conduct rather than feeling.

The Final Interpretant does not consist in the way in which any mind does act but in the way in which every mind would act. That is, it consists in a truth which might be expressed in a conditional proposition of this type: "If so and so were to happen to any mind this sign would determine that mind to such and such conduct." By "conduct" I mean action under an intention of self-control. (CP $8.315)$

Here, however, Peirce does not distinguish between the final interpretant and the ultimate logical interpretant of a sign. The latter interpretant is the logical interpretant that is not itself a sign (in the relevant respect) to another logical interpretant. Peirce argues that this interpretant is of the nature of a habit, the sort of disposition to conduct that may be described by the kind of conditional proposition he alludes to. This is the contention on which, in MS 318, Peirce's defense of pragmatism rests.

The apparent identification of final and ultimate interpretants has sometimes been brushed aside as a matter of terminology. Peirce often equates the two terms, and as he concentrated on the logical interpretant we might assume that discussion of the final emotional and energetic interpretants is simply omitted (see Short 2007: 184). However, at points it appears that Peirce identifies the ultimate logical interpretant with the final interpretant (see EP 2: 496-7). Indeed, it would not be far-fetched to assume that this problematic identification is a key reason for his difficulties in making sense of the nature of both interpretants, especially the final interpretant (as it is here called).

The immediate interpretant is a "may be", the possibility of interpretation, and the dynamical interpretant the actually formed response. The final interpretant, in turn, is a general, or a "would be". But which general? Peirce evidently runs together the notion that the final interpretant is the response that would be formed, at least under some conditions to be specified, in or by any interpreter ("the way in which every mind would act") and the idea that the final interpretant is of the nature of a habit ("a truth which might be expressed in a conditional proposition" of the habitdescribing type). In other words, Peirce does not distinguish between the would be 
that is (somehow) the response of every interpreter (which does not imply that the response must be a habit) and the would be that is a habit of conduct (which does not imply that the habit would be formed in any interpreter). This distinction remaining muddled, the final interpretant appears to be general in both ways: as the response elicited in any interpreter and as a habit of conduct.

In order for the final interpretant to be an emotional one, and not a habit of conduct, we must assume that it is general in the first of these ways: it is the response that would be elicited in any interpreter, not actually but in some conditions to be specified. ${ }^{1}$ But which response? Any actual response (dynamical interpretant) or a set thereof formed cannot be meant, as the final interpretant "does not consist in the way in which any mind does act". By the final interpretant, Peirce clearly means an interpretant that is ideal and never actualized in full. This is explained by Peirce's other remarks in which he maintains that the final interpretant would consist of everything that the sign could reveal about its object; as he puts it in a letter to William James, the final interpretant is the "sum of the Lessons of the [sign], Moral, Scientific, etc." (EP 2: 498). T. L. Short (2007: 182) quotes another typical remark from the Logic Notebook where Peirce holds that the final interpretant (here referred to as the "normal" interpretant) is the interpretant "embracing all that the sign could reveal concerning the Object to a sufficiently penetrating mind".

The final interpretant, then, is not necessarily a habit. It is a general which has at least these three features: (1) it is the response that would be, in some conditions, elicited in every interpreter; (2) it is not actualized by any dynamical interpretant, at least in full; and (3) it consists of all that the sign could reveal concerning its object.

It often seems as if the final interpretant were the whole truth concerning the sign's object. Condition (3) seems to fit uneasily with the notion of final emotional and energetic interpretants. As T. L. Short has argued, Peirce often writes as if the final interpretant were the whole truth concerning the sign's object, but this concentration on truth, according to Short (2007: 190), does not "comport to the breadth of [Peirce's] semeiotic", which extends to signs which cannot be assessed in terms of truth and falsity. Short explains such remarks by arguing that the purpose Peirce predominantly had in mind was that of the scientific inquirer, for whom the whole truth would indeed be the final interpretant of an intellectual sign. Other purposes for which signs may be interpreted - and interpretants which do not themselves admit of truth as falsity, such as actions and feelings - were thus largely neglected, but not denied, by Peirce.

The commentator raises the question of whether the final emotional interpretant could itself be a habit. The answer is that it could not: what makes an emotional interpretant (even a final one) emotional is that it is an emotion. However, the question is interesting in another respect: what if there are (not final but) ultimate emotional interpretants which are habits of feeling? This would not be Peirce's view, but possibilities of this sort should be explored. 
Attempting to rectify Peirce on this score, Short argues that the final interpretant is the interpretant that would be "ideally adequate to the purpose for which the sign is being interpreted" (Short 2007: 190). As Short notes, there are thus different final interpretants of the same sign relative to the purpose of interpretation. ${ }^{2}$

Short's account makes sense of the final interpretant as a would be in terms of its ideal adequacy. But making such adequacy relative to purpose, it also implies that the final interpretant is not the response that would be (in part) elicited in any interpreter (1). For the same reason, the final interpretant would not consist of everything that the sign can teach about its object (3). And contrary to (2), it also seems that a dynamical interpretant, if ideally adequate to the interpreter's purposes, would actualize the final interpretant (although this depends on how "ideal" the adequacy of the final interpretant is taken to be).

Short provides a tangible idea of the final interpretant by references to various interpretative purposes: this leaves room for the possibility of final emotional and energetic interpretants. Also, Short's interpretation can hardly be contested with respect to its account of Peirce's concentration on logical interpretants. Nevertheless, it may underestimate Peirce's own conception of the breadth of the final interpretant (see also Short 2007: 195). Namely, the "sum of the Lessons" that Peirce identifies with the final interpretant should not be taken narrowly as the increase of knowledge: as Peirce's words has it, the "Scientific" lessons are only some among many.

The solution that suggests itself is that the final interpretant should not be limited with respect to this or that interpretative purpose (under these or those conditions of interpretation). Rather, it should be viewed as the sum (or set) of such responses that would be adequate with respect to purposes and conditions of interpretation.

This account fits Peirce's view that (1) the final interpretant would be elicited in any interpreter under the same conditions: it encompasses any possible conditions and purposes of interpretation. It also explains why (2) the final interpretant is never fully actualized: any actually formed response, even if adequate to the conditions and purposes at hand, only actualizes one aspect of the final interpretant. Finally, (3) the final interpretant indeed entails everything that the sign could reveal about its object: there indeed is just "one" final interpretant for each sign, but that interpretant consists of a set of possible responses - the sum of the sign's lessons, very broadly understood.

Provided that there are final emotional, energetic and logical interpretants (a question to which I will return in the following section), they are all aspects of this final interpretant, distinguished as to whether the response in question is of the nature of feeling, action or thought (or habit), respectively. If this is correct, Peirce's confusion between the final and ultimate logical interpretants is also easily explained.

2 Following Short (2007: 188-189), we may enumerate signs by their immediate interpretants: the same thing can be many signs if it is differently interpretable in this manner. 
An ultimate logical interpretant of a sign - a habit - may actualize an aspect of the final interpretant, if the habit is adequate to the interpreter's purposes in those circumstances.

\section{Purposes of interpretation and dynamical objects}

The final interpretant, I have argued, can be in part actualized by a dynamical interpretant by being adequate to the purposes of interpretation. If the purpose of interpretation is to learn or know the truth, the final logical interpretant of a sign itself is a truth concerning the sign's object. But this is not the only purpose a logical interpretant may adequately serve: such interpretants may be questions, problems as well as creative ideas such as those that produce pieces of fiction. Similarly, energetic interpretants - actions - can obviously serve a variety of purposes, predominantly practical. However, the question of whether there are final emotional interpretants still remains. What purpose could a feeling serve?

It could of course be pointed out that all interpretation of signs requires a purpose: there would be no interpretants without (interpretative) purposes, as T. L. Short (2007, Ch. 6) has forcefully argued. If there are emotional interpretants, which Peirce himself distinguished, there must be interpretative purposes that those interpretants may be appropriate to. However, against this view, it could be argued that emotional interpretants are adequate only by proxy in that their mediation is required for the other interpretants to form. Emotional interpretation could be understood as a stage in an interpretative process that leads to other types of interpretants (viz., energetic and logical), which then may or may not serve a purpose of the interpreter. Our question is thus more specific and pertains to whether the emotional interpretants themselves can serve an interpretative purpose.

Clearly there are such cases. Perhaps the simplest ones involve feelings sought for for their own sake. Our purpose, say, in going to the cinema is to experience feelings elicited by a film (even if it usually is not our only purpose). The cinematic experience involves the interpretation of signs (of the film) for this purpose. Emotional interpretants may also serve more particularly practical purposes. Perhaps one may wish to decorate a beautiful home, and revises one's actions in decoration based on the feelings which imaginary and actual arrangements of colours and objects elicit. ${ }^{3}$

Finally, emotional interpretants elicited may also serve a cognitive purpose. The emotions elicited by a film may attest to the qualities of the object presented in the film, or the film itself. As a film may elicit a variety of feelings during its span and afterwards, perhaps a simpler case would concern the taste of wine, which is itself an

3 This is an example from Peirce to which we will briefly return below. 
emotional interpretant attesting to its quality. Such emotional interpretants may be further exploited to arrive at a logical interpretant, such as a judgment concerning the quality of the film or the wine. Often an emotional interpretant is rather immediately followed by such a judgment (analogously to how certain sensations are immediately followed by observational judgments). Importantly, however, no such judgments need be formed for the emotional interpretants to speak of the qualities of their objects.

In brief, emotional interpretants serve interpretative purposes by being feelings that (1) are sought for themselves; (2) serve a practical purpose; or (3) serve a cognitive purpose. Emotional interpretants may serve practical purposes by eliciting a further response which is an action or a thought - an energetic or a logical interpretant - and cognitive purposes by eliciting a thought; however, these further interpretants are not necessary for the emotional interpretant to serve the purposes enlisted. Sometimes, an emotional interpretant may be an integral part of the genuine nature of an energetic or a logical interpretant, for example when a moral judgment without a concomitant emotion (such as remorse) is as hollow as laughter (an energetic interpretant) without the feeling of amusement.

It is in order to disarm two potential misconceptions of the adequacy of interpretants. Firstly, whether an interpretant can be considered adequate depends not on all of the interpreter's purposes but on the one(s) for which the sign is being interpreted. Assume that you, upon my exclamation, jump in front of a moving car in order to save a child's life, but happen to find a winning lottery ticket instead. Your jump and the ensuing discovery may serve your other purposes (financial ones) but still fail to actualize an aspect of the exclamation's final interpretant, if the child is not saved: the latter outcome was the purpose for which the energetic interpretant (the jump) was formed.

Secondly, it might seem that emotional interpretants cannot be more or less adequate to our interpretative purposes: an emotion, we might think, cannot be mistaken. Obviously, there is a sense in which a feeling is incorrigible: it does not admit of assessment in terms of truth and falsity. But this does not imply that the feeling cannot be more or less adequate as an interpretant of a sign. This point can be made by the most unlikely example, namely the feelings that are sought for in their own right. When going to the cinema, our purpose is not merely to experience joy, sadness, and so on, but to experience the emotions the film conveys. This is precisely why our emotional responses count as interpretants of the signs that film is composed of. (In contrast, the emotions caused by a drug designed specifically to make people happy would not be interpretants of a sign.)

In both cases just discussed, the adequacy of the interpretant does not simply depend on the interpreter's purposes; it also depends on the nature of the sign's dynamical object, the object "as it is regardless of any particular aspect of it, the Object 
in such relations as unlimited and final study would show it to be" (EP 2: 495). ${ }^{4}$ As all signs have final interpretants, all signs also have dynamical objects: such objects are required to explain the discrepancy between dynamical and final interpretants. A dynamical interpretant may be a completely inadequate response to the sign, in which case that interpretant does not actualize any part of the final interpretant. But even when the dynamical interpretant is an adequate response, and hence actualizes an aspect of the final interpretant, it will nevertheless do so only partially: there is always more a sign could reveal concerning its object. ${ }^{5}$

\section{Emotional interpretants and ethical claims}

I have argued that emotional interpretants - feelings - can serve a variety of interpretative purposes, and that their adequacy in serving those purposes ultimately depends on the nature of the dynamical objects of the signs of which they are interpretants. If this much is correct, there are final emotional interpretants, and an actual feeling (a dynamical interpretant) can actualize an aspect of the final emotional interpretant: the feeling can be adequate to an interpretative purpose with respect to the sign's dynamical object. Feelings, then, can be more or less appropriate as responses depending, in part, on the dynamical object of the sign. This opens the possibility of treating feelings as an aspect of experience that itself can be revealing of the nature of those dynamical objects.

As we have seen, Peirce maintains that all interpretation of signs is founded on emotional interpretants, which are the first responses in a chain that may further produce energetic and logical interpretants. However, the most interesting use that Peirce makes of emotional interpretants, at least in MS 318, concerns the development of purposes. He enlists feelings - either attractive or repulsive - as leading us to revise

4 Sometimes, also in MS 318, it seems that Peirce connects the emotional interpretant with the sign's immediate object, whereas the energetic and logical interpretants are connected with the dynamical object. It is however not immediately clear why the emotional interpretant would not be connected to the dynamical object quite as well as the other two interpretants. It may be that here Peirce does not make a clear distinction between the immediate and dynamical interpretants, the former of which is matched - indeed, in a sense identical - with the immediate object. I am indebted to Mats Bergman for discussions on this point.

5 Short defines the dynamical object as that which explains any discrepancy between the sign's immediate and final interpretants. In accordance with his interpretation of the final interpretant, Short attempts to avoid the identification of that interpretant with what "unlimited and final study would result in" (Short 2007: 191). However, with the emendation to Short's interpretation here proposed, there is no reason to avoid such identification. Accordingly, as in the examples just discussed, we may understand the dynamical object as explaining any discrepancy between the dynamical and final interpretants. 
our purposes by way of efforts of reproducing them by way of similar conduct, drawing from an example of a builder who, with the "general purpose to render the decorations of a house he is building beautiful" makes "decorations in his inner world, and on attention to the results, in some cases experienced feelings stimulated him to endeavors to reproduce them, while in others [...] excited efforts to avoid and modify them" (EP 2: 431). Here we have emotional interpretants (feelings) leading to energetic interpretants (efforts) which, by way of reiteration, bring about a logical interpretant (a purpose), serving the practical purpose of decoration.

Purposes, in Peirce's view, are the mental states which entail or dictate the aims of self-controlled conduct; like habits, they are general. They are thus the sort of mental states or dispositions that we would assume that a person who assents to, or sincerely asserts, a normative proposition would entertain. For this reason, as I have argued at more length elsewhere, they could be viewed as the ultimate logical interpretants of normative (as opposed to descriptive) judgments or propositions (Rydenfelt in press). ${ }^{6}$ The development of purposes in light of feelings, as discussed by Peirce, is, by these lights, the revision of normative views of all stripes: moral propositions, logical rules of thought, conventional prescriptions, as well as what seem to be mere expressions of taste or preference.

The development of purposes, however, does not always require an ulterior purpose, whether practical - such as in the builder example - or cognitive. Sensations can sometimes lead to spontaneous and apparently uncontrolled descriptive judgments, often called observations. Similarly, normative judgments are sometimes brought about without control, such as when an emotional response instantly sparks an ethical judgment, itself a logical interpretant. (I will here stay neutral on whether judgments of a normative nature based on feelings should be understood as distinct from, or as a subclass of, such observations.) Witnessing some horrid action quite spontaneously leads to the judgment that what occurred was wrong, conveyed by an emotional interpretant (a feeling of indignation or the like). Of course, this is not the only source of our normative views, just like (other) observations are not the only source of our beliefs.

However, a prospect based on Peirce's discussion is that feelings could be harnessed in order to revise our opinions, or exploited for specifically cognitive purposes. This concerns cases in which we attempt to ascertain whether something really is funny, depressing, cheerful, or the like; but more importantly to the issues at hand, the cognitive purposes might be those of ethical inquiry. Norms (statements concerning what should be) could be understood as analogous to theories (statements concerning what is or would be), both revisable based on experience, where the relevant experience

6 This view runs counter to Peirce's own claim, in MS 318, that a purpose is merely the "character" of a self-controlled habit. 
concerning norms is distinctly emotional in nature, dependent on attractive and repulsive feelings of moral pertinence, such as approval or indignation. In particular, moral norms, or general propositions concerning how we should act under certain conditions, could be understood by analogy to scientific laws, or propositions concerning what would occur in certain conditions. ${ }^{7}$

It might be retorted that feelings are "merely" subjective, and judgments based on them are culturally and socially laden; but the same is the case of sensations and the observations they found. Similarly, it could be argued that this approach to emotions as the experience founding certain judgments makes features such as rightness and wrongness (or cheerfulness or dullness) of the dynamical objects of signs dependent on our emotional reactions towards those signs. However, this would be mistaking the view proposed for a conceptual reduction of these features to our responses. ${ }^{8}$ Consider again the analogy with "descriptive" observations. While our judgments of, say, whether stones are hard are based on sensations, the hardness of stones itself does not consist of those responses. There is no apparent reason to think that the features of the dynamical objects that elicit our emotional responses are are fundamentally different.

There are, of course, salient differences between observations based on sensations and judgments based on feelings pertinent to, say, ethical inquiry. One such difference is that the latter kind of judgments do not (at least as of yet) allow for the sort of precision that could be brought about by the development of instruments of measurement. However, as T. L. Short (2008; see also Short 2015) has argued, Peirce himself made use of feelings for scientific purposes in his "Study of great men" conducted with his students at Johns Hopkins in 1883-1884, where the students assessed the greatness of historical individual on the basis of brief biographical sketches, on a scale of 1 to 6 , resembling the Ptolemaic classes of stellar magnitudes. The point of this study, as

\footnotetext{
7 The commentator argues that "emotions should have a kind of propositional content, otherwise they would never be turned into judgments". But this seems to me a non sequitur. Peirce distinguished between the percept (a secondness that professes nothing) and the perceptual judgment (a thirdness, a thought that "represents") (see Bergman 2007). An emotion may be treated analogously to the percept and a normative claim to the perceptual judgment. There is much debate on these issues in the philosophy of perception, of course, but almost everyone agrees that in perception or observation something that is not itself a judgment founds a judgment. In Peirce's terms the percept is the non-judgment on which the perceptual judgment is based. If that is a viable approach, it can be extended to the relationship between emotions and normative judgments.

8 Indeed, it seems my commentator may be guilty of this mistake. I do not wish to propose that the emotionally "tractable" features of objects are themselves the same as, or dependent on, our emotional responses (or judgments based on them), any more than the hardness of a stone consists of, or is dependent on, our sensations (or judgments based on them).
} 
Peirce reports decades later, was to "explode the ordinary notions that mathematical treatment is of no advantage when observations are devoid of precision and that no scientific use can be made of very inexact observations" (CP 7.256). ${ }^{9}$

Another difference between descriptive and normative judgments appears to be that feelings that are relevant to normative judgments can be brought about by simple contemplation, while the sensations funding "descriptive" observations are less amenable to imagination, often requiring external experimentation. Both are nevertheless dependent on experience. For example, thought experiments concerning moral questions are indeed experiments: they are not mere deductions from a set of pre-existing background principles (or a priori), but funded by the feelings elicited by the contemplation of imaginary circumstances (or a posteriori).

The view here proposed can be further clarified by some remarks on its relationship to moral sentimentalism. ${ }^{10}$ Sentimentalism can be understood as one, or a combination, of (at least) the following views concerning moral judgments: that such judgments (1) express emotions (emotivism); (2) are judgments concerning emotions; (3) are explained by emotions; and (4) are justified by emotions. By the view at hand, making a moral judgment or holding a moral view is not to be in an emotional state or to express such a state (or 1): it is, rather, making a judgment like any other. Neither are moral judgments judgments about emotions: they do not concern or make reference to what emotions we do, could or should have (or 2). As a consequence, moral "facts" are not themselves facts about emotions. The latter two sentimentalist claims come closer to the view proposed, by which moral judgments may be sparked by emotions and indeed often seem to be. However, if sentimentalism requires that the explanation of moral judgments is always explained by an emotion (or 3), the view proposed does not insist on such an explanation: moral judgment need not arise with, or be accompanied by, a feeling. The source of moral judgments is often elsewhere, such as in what we have learned from others.

The sentimentalist view of the justification (or 4) comes closest to the view proposed. Sentimentalists sometimes claim that emotions justify our moral judgments, often limiting the salient emotions to those that are suitably neutral with respect to individual interests. However, I have not suggested that the actual procedures of justification of moral judgments that we engage in are always founded on emotions.

9 Peirce's notion of inexactness in this connection does not completely agree with the term's common usage: it does not refer to a lack of discrimination on e.g. a scale but to the difficulty of arriving at an observational judgment (see Short 2008).

10 This and the following paragraph have been added as a response to the commentator, who raises the interesting question of the extent to which the view proposed here is a sentimentalist one, along the lines of Shaftesbury and Hume, pointing out that Peirce was not a sentimentalist and in any case not an emotivist. I agree that Peirce was not a Humean sentimentalist nor an emotivist, and I wish to defend neither view. 
Quite the contrary, it seems clear that they often are not - say, in cases when people justify their moral views by referring to some moral authority, such as a religious text. The suggestion at hand is that emotions could be exploited in justifying moral opinion, and indeed systematically so, in ethical inquiry. Even here it must be emphasized that no emotion, as such, suffices to justify a moral judgment any more than a sensation suffices to justify a "descriptive" judgment; much more by way of auxiliary beliefs and hypotheses is required for an emotionally founded judgment to be taken to count in favour (or against) a moral view.

\section{Conclusion}

I have argued that there are such things as final emotional interpretants: emotional interpretants can serve interpretative purposes. Whether they do so adequately whether they succeed in serving interpretative purposes - depends, ultimately, on the signs' dynamical objects. In this way, emotional interpretants can be revealing of those objects. The prospect that I then explored was that of harnessing emotional interpretants for a particular cognitive purpose, that of ethical inquiry. Analogously to the role played by descriptive judgments (or observations) funded by sensations in non-normative inquiry, normative judgments based on feelings can serve as the observational part of normative inquiry. ${ }^{11}$

\section{References}

Bergman, Mats 2007. Representationism and presentationism. Transactions of the Charles S. Peirce Society 43(1): 53-89.

Peirce, Charles Sanders 1931-1958. Collected Papers of Charles Sanders Peirce. (8 vols. Hartshorne, Charles; Weiss, Paul, eds., vols. 1-6; Burks, Arthur W., ed., vols. 7-8.) Cambridge: Harvard University Press. [In-text references are to CP, followed by volume and paragraph numbers.]

- 1992, 1998. The Essential Peirce. (2 vols.; Houser, Nathan; Kloesel, Christian; the Peirce Edition Project, eds.) Bloomington: Indiana University Press. [In-text references are to EP, followed by volume and page numbers.]

Rydenfelt, Henrik in print. Habits, purposes and pragmatism, In: Švantner, Martin; Gvoždiak, Vít (eds.), How to Make Signs Clear: Sources, Problems and Limits of Peirce's Sign Theory. Leiden: Brill.

Short, Thomas L. 2007. Peirce's Theory of Signs. Cambridge: Cambridge University Press.

- 2008. Measurement and philosophy. Cognitio: Revista de Filosofia 9(1): 111-124.

- 2015. Empiricism expanded. Transactions of the Charles S. Peirce Society 51(1): 1-33.

11 I am indebted to Mats Bergman, T. L. Short and a commentator for comments on an earlier version of this paper. 


\title{
Эмоциональные интерпретанты и этический запрос
}

Связь между эмоциями и этическими взглядами интересовала многих философов. Основываясь на пирсовской трактовке эмоциональных интерпретант (MS 318), предлагаю использовать такие интерпретанты в исследованиях по этике. В начале статьи я утверждаю, следуя за Т. Л. Шортом, что существуют финальные эмоциональные интерпретанты. Те эмоциональные интерпретанты, которые фактически сформированы (динамичные интерпретанты), могут быть более или менее соответствующими (динамическим) объектам знака. Затем я исследую возможность использования эмоциональных интерпретант в этике с когнитивной целью, приходя к выводу, что основанные на чувствах нормативные суждения могут составить наблюдаемую часть подобного этического запроса.

\section{Emotsionaalsed tõlgendid ja pärimine eetika järele}

Emotsioonide ja eetiliste vaadete vaheline side ehk pärimine eetika järele on huvitanud mitmeid filosoofe. Selle põhjal, kuidas Peirce (MS 318) käsitleb emotsionaalseid tõlgendeid, panen ette, et selliseid tõlgendeid saaks kasutada pärimises eetika järele. Kõigepealt väidan, lähtudes T. L. Shorti Peirce'i tõlgendusest, et on olemas lõplikud emotsionaalsed tõlgendid, sellised emotsionaalsed tõlgendid, mis on tegelikult moodustunud (või dünaamilised) ja võivad olla märgi (dünaamiliste) objektide suhtes rohkem või vähem kohased. Seejärel uurin võimalust, kas emotsionaalseid tõlgendeid saab rakendada eetika järele pärimise konkreetse kognitiivse eesmärgi huvides, jõudes järeldusele, et tunnetel põhinevad normatiivsed otsused võivad moodustada selle vaadeldava osa.

\section{COMMENT: \\ A note on moral sentimentalism in the light of the emotional interpretant}

\author{
Jean-Marie Chevalier ${ }^{12}$
}

This very nice paper on emotional interpretants and ethical inquiry suggests that moral norms might be somehow based on feelings. More precisely, it argues for the idea that emotional interpretants could be exploited in ethical inquiry. The broad thesis that ethics rests on a special kind of sentiments or feelings has been defended in the history of philosophy under the label of Moral Sentimentalism. Shaftesbury is one of its main supporters. He held that a "Sense of Right or Wrong" allows us to evaluate the "affection" behind actions, thus forming a second-order affection (Shaftesbury 2001[1699-1714]). What is this sensibility to the good and

12 Author's address: Department of Philosophy, University of Helsinki, Yliopistonkatu 4, 00100 Helsinki, Finland; e-mail: jeanmariechevalier@yahoo.fr. 
evil? Hume famously claimed that the so-called moral sense needs to be analysed as specific mechanisms, among which sympathy plays a fundamental role.

In the wake of this, Henrik Rydenfelt seems to be proposing a view based on the Peircean analysis of the emotional interpretant. In his version, a feeling is not precisely a reason on which to base a moral judgment, but - if I understand it correctly - a reason for striving to reproduce some actions in order to reach a purpose ${ }^{13}$ ("leading us to revise our purposes by way of efforts of reproducing them by way of similar conduct"). The idea that the logical interpretant of a normative proposition should be a purpose is palatable. In this view, feelings would help develop purposes, and thence, revise normative judgments.

How do feelings work in this direction? The author's example goes: the perception of a wrong action produces an emotional interpretant (namely, a negative emotion, e.g. disgust, indignation or fear), which "spontaneously leads" to a moral judgment (of disapproval). The author admits it does not mean that all our moral judgments are uncontrolled, but he seems inclined to view the spontaneous transition from feelings to judgments as the normal mode of formation of moral evaluation. It may be a bit unclear whether the author claims that we do most of the time base our moral assessments on feelings, or that we should "harness" them in order to achieve the purposes of ethical inquiry.

The crux of such kind of a theory is of course to explain how normative judgments "spontaneously" proceed from feelings. The author is aware that making "features such as rightness and wrongness (or cheerfulness or dullness) of the dynamical objects of signs dependent on our emotional reactions" faces many objections. They may be summed up in the celebrated Humean maxim that we cannot infer "ought" from "is": in particular, what we ought to praise cannot be deduced from what we feel. Ethics is epistemically autonomous, and may not be derived from mere observation of inner (or outer) states. Nevertheless, one can try to elaborate on the analogy with empirical observation.

Rydenfelt's solution is exciting. He proposes that emotional interpretants might be conceived on the model of perception. To be true, gut reaction often precedes (and perhaps causes) moral judgments. But is the emotional response a perception? If so, it is required that emotions should have a kind of propositional content, otherwise they would never be turned into judgments - just like a judgment of observation requires that perceptions should have some sort of conceptual content. However, those who claim that emotions have intentional content must explain how emotions may be feelings and judgments at the same time - claiming for instance that they involve the judgment that their objects have the property which is the content of the emotion (e.g., that fear of a bear involves the judgment that the bear has the property of being frightening). The supporters of such representational theories also have to define what we perceive in emotion - most of them arguing that emotions present values (e.g. Tappolet 2000).

The analogy with perception drawn by Rydenfelt paves the way to an interesting alternative. As Peirce seems to have implied that the logical interpretant is all-embracing, all aspects (including emotional) should be accounted for within his model of scientific inquiry. On this basis, one can regard propositions about right and wrong "in analogy to scientific laws": just like scientific laws are general propositions whose truth may virtually be tested by a practical

13 As the author stipulates it, 'purpose' is here meant as the mental state equivalent to the aim of an action. 
controlled procedure (relying on a real would-be), moral judgments would result from possible practical tests based on a specific kind of observation, namely the observation of emotions. It reveals that emotional interpretants should not be viewed as subjective feelings but as somehow general, a requirement that Hume had noticed: “Tis only when a character is considered in general, without reference to our particular interest, that it causes such a feeling or sentiment, as denominates it morally good or evil" (Hume 1978[1739-1740]: 472). It does not imply that the whole theory of ethics should rest on feelings, but, as Rydenfelt puts it, "normative judgments based on feelings can serve as the observational part of such inquiry".

One can only encourage the author to explore this direction, perhaps in working out the conception of emotion and feeling in the way Peirce did regarding perception, separating a percept from a percipuum and perceptual judgment. It parallels the concept, conception and conceptual judgment trichotomy. Would it be relevant to introduce differences between the felt, the "motuum" and the emotional judgment? At any rate, what is conveyed in the emotional interpretant is more than mere feeling: it is the whole meaning of an object that can be encapsulated in emotion. For that reason, the Peircean notion of emotional interpretant may help to circumvent some shortcomings of judgmental theories of emotion.

It seems to me that the view defended by Rydenfelt significantly differs from Peirce's own view (which of course is no argument against the former). It is true that Peirce regarded sentiments as fundamental in guiding one's behaviour: "certain kinds of conduct, when the man contemplates them, have an esthetic quality. He thinks that conduct fine; and though his notion may be coarse or sentimental, yet if so, it will alter in time and must tend to be brought into harmony with his nature" (CP 1.591, 1903). Nevertheless, it is dubitable that Peirce was a moral sentimentalist in the Humean sense. ${ }^{14}$ Hookway (2000: 228) showed that Peirce had a cognitivist view of emotion and sentiment which forbids any ethical emotivism. It is true that, as the author writes: "A moral judgment without a concomitant emotion (such as remorse) is as hollow as laughter (an energetic interpretant) without the feeling of amusement". But it does not imply that the moral judgment consists in the emotion. If not through emotion, how do we know what is good and bad according to Peirce? He was never very eloquent about that. Our "sensible heart" indeed makes "natural judgments" (W 8.188). But there may be a more conceptual way of telling the good from the evil. When explaining the role of icons and indices in predication, Peirce gives the following example:

14 Peirce's "apology for philosophical sentimentalism" does not exactly defend moral sentimentalism in the Humean sense. It is rather the view that philosophical rationalism is "a farce" (CP 1.631, 1898 = EP 2.32) because the rational reasons we provide to most of our choices are often a posteriori justifications. In this view, reason "appeals to sentiment in the last resort" (CP $1.632,1898$ ) because most of our actions are guided by instinct. Without any paradox, it goes with the claim that not "any weight whatsoever" should be allowed to sentiment or instinct in theoretical matters (CP 1.634, 1898). Sentimentalism, when understood not as "the fashionable amusement to spend one's evenings in a flood of tears over a woeful performance on a candlelitten stage" (W 8.188) but as the true doctrine that "great respect should be paid to the natural judgments of the sensible heart" (W 8.188), "ought to lie at the cornerstone of all our conduct" (CP 1.662). 
Suppose, for example, I detect a person with whom I have to deal in an act of dishonesty. I have in my mind something like a 'composite photograph' of all the persons that I have known and read of that have had that character, and at the instant I make the discovery concerning that person, who is distinguished from others for me by certain indications, upon that index at that moment down goes the stamp of RASCAL, to remain indefinitely. (CP 2.441, c. 1893)

It may not solve the problem of our sensibility to moral appraisal, but Peirce's idea is that we form a moral judgment (a symbol) in voluntarily associating an icon with an object presented to us by an index. As Peirce often uses the metaphor of composite photographs to describe the way we form concepts, one can surmise mere sensibility is not enough for such a process to take place.

Of course, one of the assets of Rydenfelt's view is that the emotional interpretant is subtler than a feeling. Yet it makes it more mysterious too. As he argues that "there must be such things as final emotional interpretants" and that "all signs actually interpreted have dynamical emotional interpretants", one would like to find an example of the "purest" kind of emotional interpretant. A mere "feeling of interpretability" is minimal. Maybe the interpretant of an instrumental piece of music would be fully emotional. ${ }^{15}$ Through it, no "signification" is conveyed (nothing that could be expressed in a true or false proposition), and still, an adequate response may be expected: although "an emotion, we might think, cannot be mistaken," feeling static on a waltz or depressed by Beethoven's "Ode to Joy" would clearly be inadequate, not because it does not fit with the composer's intention, but because it does not fit with music itself. T. L. Short's definition that the interpretant should be "ideally adequate to the purpose for which the sign is being interpreted" (Short 2007: 190) posits a purpose which may be ethical; but in the case of a symphony, no such purpose exists. And as Rydenfelt notes, being relative to a purpose seems to prevent it from being elicited in any interpreter.

It raises the question of the absolute end of purely aesthetic signs (if any, perhaps such as instrumental music). Is it possible that their complete ultimate interpretant should be emotional? If so, what is the adequate end for a work of "pure" art? In Peirce's pragmaticism, logic has a definite adequate end, which is its norm: truth as the final opinion of the community. Ethics has too, namely self-controlled conduct. What about the end of aesthetics? It is one of the systems' blind spot. The summum bonum, which is supposed to be the ground of any other norm, parallels the emotional interpretant, supposed to be part of any (dynamical) interpretant as its possibility. So the adequacy of an emotional interpretant (e.g. of a symphony) would be evaluated in comparing its object to the summum bonum. This may not be very helpful, though; anyway, it raises the question of what is the signification of a sign, when its meaning is neither logical nor obviously practical. This may lead to a general theory of "natural dicisigns" (Stjernfelt 2014).

If the final emotional interpretant is the adequate emotion felt when viewing or hearing (and, why not, tasting) a piece of art in particular, why could it not be a habit? The adequate

15 The author gives the example of movies as a kind of entertainment where "feelings [are] sought for for their own sake". But a movie is eminently complex, and requires a strong logical interpretation. As for the example of wine tasting, it raises the problem of the difference between feeling, sensation and emotion, with which I tried to deal (Chevalier 2007). 
interpretation should grow more and more steady and regular. It is true that habit usually belongs to Thirdness and logic. Furthermore, a habitual feeling probably would not be very emotional: it would lack spontaneity and eventually be dead. However, maintaining that an emotional interpretant may be a habit would reconcile final interpretants with feelings. For if the interpretant is a response elicited in any interpreter, it seems to me that it must be a habit: if anyone behaves in the same way, it is a regularity that people behave so; and the multiplicity of agents all responding alike is equivalent to a single agent always responding alike. This separation of the would-be into two senses (common response and habit) does not seem necessary to me; it is my major point of resistance to the paper by Rydenfelt, which is otherwise extremely convincing.

\section{References}

Chevalier, Jean-Marie 2007. Les émotions ont-elles une place en logique? Un examen de la réponse peircienne. Organon 36: 165-181.

Hookway, Christopher 2000. Truth, Rationality and Pragmatism. Oxford: Clarendon Press. Hume, David 1978[1739-40]. A Treatise of Human Nature. (Selby-Bigge, Lewis Amherst; Nidditch, Peter H., eds.). Oxford: Clarendon Press.

Peirce, Charles S. 1931-1958. Collected Papers of Charles Sanders Peirce. Cambridge: Harvard University Press. (Hartshorne, Charles; Weiss, Paul; Burks, Arthur W., eds.). [In-text references are to $\mathrm{CP}$, followed by volume and paragraph numbers.]

- 1982-. The Writings of Charles S. Peirce: A Chronological Edition. Bloomington: Indiana University Press. (Fisch, Max H. et al., eds.) [In-text references are to W, followed by volume and page numbers.]

- 1998. The Essential Peirce. Vol. 2. Bloomington: Indiana University Press. (Houser, Nathan et al., eds.) [In-text references are to EP, followed by volume and page numbers.]

Shaftesbury, Third Earl of [Anthony Ashley Cooper] 2001[1699-1714]. An inquiry concerning virtue and merit. In: Characteristicks of Men, Manners, Opinions, Times. Vol. 2. (Den Uyl, Douglas J., ed.) Indianapolis: Liberty Fund, 1-100.

Short, Thomas L. 2007. Peirce's Theory of Signs. Cambridge: Cambridge University Press.

Stjernfelt, Frederik 2014. Natural Propositions: The Actuality of Peirce's Doctrine of Dicisigns. Boston: Docent Press.

Tappolet, Christine 2000. Emotions et Valeurs. Paris: Presses Universitaires de France. 